\title{
Assessment of permafrost distribution maps in the Hindu Kush Himalayan region using rock glaciers mapped in Google Earth
}

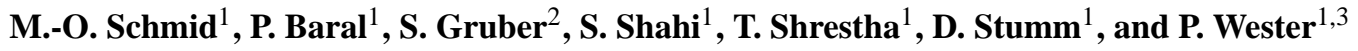 \\ ${ }^{1}$ ICIMOD, International Centre for Integrated Mountain Development, G.P.O. Box 3226, Kathmandu, Nepal \\ ${ }^{2}$ Department of Geography \& Environmental Studies, Carleton University, Ottawa, Canada \\ ${ }^{3}$ Water Resources Management group, Wageningen University, Wageningen, the Netherlands \\ Correspondence to: M.-O. Schmid (marcolivier.schmid@gmail.com)
}

Received: 30 July 2014 - Published in The Cryosphere Discuss.: 15 October 2014

Revised: 30 October 2015 - Accepted: 3 November 2015 - Published: 11 November 2015

\begin{abstract}
The extent and distribution of permafrost in the mountainous parts of the Hindu Kush Himalayan (HKH) region are largely unknown. A long tradition of permafrost research, predominantly on rather gentle relief, exists only on the Tibetan Plateau. Two permafrost maps are available digitally that cover the HKH and provide estimates of permafrost extent, i.e., the areal proportion of permafrost: the manually delineated Circum-Arctic Map of Permafrost and Ground Ice Conditions (Brown et al., 1998) and the Global Permafrost Zonation Index, based on a computer model (Gruber, 2012). This article provides a first-order assessment of these permafrost maps in the HKH region based on the mapping of rock glaciers.

Rock glaciers were used as a proxy, because they are visual indicators of permafrost, can occur near the lowermost regional occurrence of permafrost in mountains, and can be delineated based on high-resolution remote sensing imagery freely available on Google Earth. For the mapping, 4000 square samples $\left(\sim 30 \mathrm{~km}^{2}\right)$ were randomly distributed over the HKH region. Every sample was investigated and rock glaciers were mapped by two independent researchers following precise mapping instructions. Samples with insufficient image quality were recorded but not mapped.

We use the mapping of rock glaciers in Google Earth as first-order evidence for permafrost in mountain areas with severely limited ground truth. The minimum elevation of rock glaciers varies between 3500 and $5500 \mathrm{~m}$ a.s.l. within the region. The Circum-Arctic Map of Permafrost and Ground Ice Conditions does not reproduce mapped conditions in the HKH region adequately, whereas the Global Permafrost Zonation Index does so with more success. Based on
\end{abstract}

this study, the Permafrost Zonation Index is inferred to be a reasonable first-order prediction of permafrost in the HKH. In the central part of the region a considerable deviation exists that needs further investigations.

\section{Introduction}

Permafrost underlies much of the Earth's surface and interacts with climate, ecosystems, and human systems. The interaction between permafrost, or its thaw, and human activity is diverse and varies with environmental and societal conditions. Examples include ground subsidence, vegetation change on pasture, slope instability, hydrological change, damage to infrastructure, and special requirements for construction. This list is not exhaustive and it is likely that climate change will bring about unexpected permafrost phenomena and societal impacts in the future (cf. Gruber, 2012; IPCC, 2014). A large proportion of the global permafrost region is situated in mountain terrain. This includes densely populated areas especially in the European Alps and Asian high-mountain ranges. While permafrost in European mountains and its associated climate change impacts are comparably well investigated, little is known about permafrost in many Asian mountain ranges. In this study, we focus on the Hindu Kush Himalayan (HKH) region, which we use as one way for delineating a study region in the mountains of South and Central Asia (Fig. 1). The HKH region includes mountains in parts of Afghanistan, Bhutan, China, India, Myanmar, Nepal, and Pakistan (Fig. 1). Comprised mostly of high-elevation rugged terrain, including the Ti- 


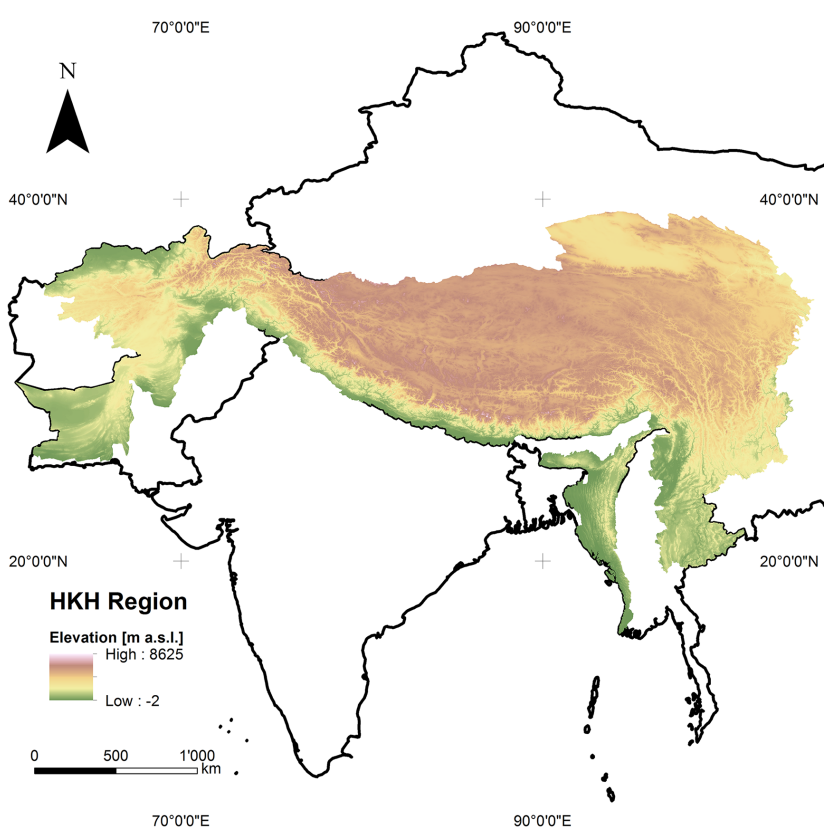

Figure 1. The HKH region as defined by ICIMOD which includes high mountains in Afghanistan, Bhutan, China, India, Myanmar, Nepal, and Pakistan. SRTM DEM version 4.1 from CGIAR at a spatial resolution of $90 \mathrm{~m}$ (Jarvis et al., 2008) shown in the WGS84 coordinate system.

betan Plateau, the Hindu Kush, Karakoram, and Himalayan mountain ranges, more than half of its 4.5 million $\mathrm{km}^{2}$ are located above $3500 \mathrm{~m}$ a.s.l. As the source of the 10 largest Asian river systems, the HKH region provides water, ecosystem services, and the basis for livelihoods to an estimated population of more than 210 million people in the mountains and 1.3 billion people when including downstream areas (Bajracharya and Shrestha, 2011). While glaciers and glacier change have received considerable research attention in recent years (e.g., Bolch et al., 2012), large areas of permafrost in the HKH region have barely or only partially been investigated. The Tibetan Plateau, as the only part of the HKH region, has a long tradition of permafrost research (Cheng and $\mathrm{Wu}, 2007$; Yang et al., 2010; Zhang, 2005); most of these studies, however, focus on a narrow engineering corridor and/or on rather gentle relief. Ran et al. (2012) provide an overview and comparison of the several Chinese permafrost maps that include the Tibet Plateau and that reflect several decades of research and development in this area. For locations with mountainous topography only sporadic information exists, especially along the southern flanks of the Himalayas (Owen and England, 1998; Shroder et al., 2000; Ishikawa et al., 2001; Fukui et al., 2007a; Regmi, 2008). Only two permafrost maps are available digitally that cover the HKH region and provide estimates of permafrost extent, i.e., the areal extend of permafrost: a. The Circum-Arctic Map of Permafrost and Ground Ice Conditions (cf. Heginbottom et al., 1993; Brown et al., 1998) published by the International Permafrost Association (IPA map). It is based on manually delineated polygons of classes (continuous, discontinuous, sporadic, isolated patches) of permafrost extent (Heginbottom, 2002). The map has been digitized and is available digitally from the Frozen Ground Data Center at the National Snow and Ice Data Center (NSIDC), Boulder, Colorado, USA.

b. The Global Permafrost Zonation Index (PZI), available on a spatial grid of about $1 \mathrm{~km}$ resolution (Gruber, 2012). PZI is an index representing broad spatial patterns but it does not provide actual permafrost extent or probability of permafrost at a location. It is based on a mathematical formulation of permafrost extent as a function of mean annual air temperature, a $1 \mathrm{~km}$ digital elevation model (DEM) and global climate data. The parameterization is based on rules similar to those employed for the IPA map. Additionally, the uncertainty range is explored (a) with three parameter sets describing a best guess as well as conservative and anticonservative estimates of permafrost extent and (b) using spatial fields of air temperature derived from global climate reanalysis (NCAR-NCEP) and from interpolated station measurements (CRU TS 2.0). Uncertainty is expressed in the resulting map product with a "fringe of uncertainty", referring to a permafrost extent greater than $10 \%$ in the coldest of the diverse simulations performed.

The application of either map in the mountainous parts of the HKH region is not straightforward, because (a) little information on mountainous permafrost exists to establish their credibility; (b) the range of environmental conditions in the $\mathrm{HKH}$ region is large and subject to conditions (such as monsoonal summer precipitation, hyperaridity, or extreme elevation) for which only limited knowledge exists; and (c) only few remote, high-elevation meteorological stations exist, usually in valley floors, making the application of gridded climate data or the estimation of conditions in remote high-elevation areas error-prone. The required testing or calibration of models (maps) of permafrost extent, unfortunately, is difficult and often avoided (Gruber, 2012), both for lack of data and for lack of methods for comparing point observations such as boreholes with spatial estimates of permafrost extent.

This study provides a first-order assessment of these two permafrost maps in the mountainous part of the HKH region. We use the qualifier "first-order" as only direct observation of permafrost can provide a reliable evaluation. In the absence of reliable information on permafrost in this region, such a first-order assessment is useful as it adds relevant information on the approximate areas of permafrost occurrence. We use rock glaciers as a proxy, because they are visual indicators of permafrost, they can exist near the 
lowermost regional occurrence of permafrost in mountains (Haeberli et al., 2006), and they can be delineated based on high-resolution remote sensing imagery freely available on Google Earth. Our objectives are to (a) develop a rock glacier mapping procedure that is suitable for application on Google Earth, (b) map rock glaciers in randomly distributed square samples over the entire HKH region and perform quality control on the resulting data, and (c) based on the mapped rock glaciers assess available permafrost distribution maps.

\section{Background}

The term rock glacier is used to describe a creeping mass of ice-rich debris on mountain slopes (e.g., Capps, 1910; Haeberli, 1985). The presence of ground ice at depth, usually inferred from signs of recent movement, is indicative of permafrost. In areas with a continental climate, commonly found in the $\mathrm{HKH}$ region, surface ice interacts with permafrost and results in complex mixtures of buried snow or glacier ice and segregated ice formed in the ground. In such environments all transitions from debris-covered polythermal or cold glaciers to ice-cored moraines and deep-seated creep of perennially frozen sediments occur (e.g., Owen and England, 1998; Shroder et al., 2000; Haeberli et al., 2006).

The occurrence of rock glaciers is governed not only by the ground thermal regime but also by the availability of subsurface ice derived from snow avalanches, glaciers, or ice formation within the ground. Furthermore, sufficient supply of debris and topography steep enough to promote significant movement are required. Therefore, the presence of intact rock glaciers can be used as an indicator of permafrost occurrence, but the absence of intact rock glaciers does not indicate the absence of permafrost. As intact rock glaciers contain ice (latent heat) and move downslope, their termini can be surrounded by permafrost-free ground. The frequently occurring cover of coarse clasts promotes relatively low ground temperatures and thereby further retards the melting of the ice within the rock glacier. In steep terrain, this makes termini of rock glaciers local-scale indicators for the presence of permafrost, sometimes occurring at an elevation indicative of the lowermost regional occurrence of permafrost in mountains (Haeberli et al., 2006). This tendency of being among the lowermost occurrences of permafrost in an area is exploited in this mapping exercise. In more gentle terrain, such as parts of the Tibetan Plateau, not the ground thermal conditions (i.e., the presence of permafrost) but the slope angle is the limiting factor. As a consequence, rock glaciers can be absent over large areas of permafrost due to the lack of debris, low slope angles, lack of avalanche snow, or the elevation of the valley floor.

The spatially heterogeneous ground thermal regime and the frequent existence of permafrost-free areas directly adjacent to rock glaciers makes the concept of "lower permafrost limits" impractical as these limits are neither measurable nor clearly defined and consequently we avoid this concept despite its prevalence in the literature. As an example, the data and statistical analyses presented by Boeckli et al. (2012) show that mean annual ground temperature can vary by 10 $15^{\circ} \mathrm{C}$ locally, i.e., while subject to the same mean annual air temperature. In this varied pattern of ground temperatures, rock glaciers often are among the lowest regional occurrences of permafrost, given sufficient moisture supply and topography. At elevations lower than the lowest rock glaciers in a region, very little permafrost is to be expected whereas the proportion (extent) of permafrost usually increases towards higher elevations.

Rock glaciers are a widespread feature in many parts of the $\mathrm{HKH}$ region, but very limited research has been conducted on them. For the northern regions of India and Pakistan, in the Karakoram Range, lowermost elevations of active rock glaciers vary between 3850 and $5100 \mathrm{~m}$ a.s.1.. Inactive rock glaciers were even recorded at lower elevations with a minimum elevation of $3350 \mathrm{~m}$ a.s.l. in the western Karakoram Range (Hewitt, 2014). A significant increase in the number of rock glaciers is seen from monsoon-influenced regions in the east to the dry westerly influenced regions with annual precipitation being below $1000 \mathrm{~mm}$ (Owen and England, 1998). From the Khumbu region in Nepal, lowermost occurrences of active rock glaciers are reported to be between 5000 and $5300 \mathrm{~m}$ a.s.1. (Jakob, 1992). Further east in the Kangchenjunga Himal of Nepal, the distribution of rock glaciers varies from $4800 \mathrm{~m}$ a.s.l. on the northern aspect to $5300 \mathrm{~m}$ a.s.l. on the south- to east-facing slopes (Ishikawa et al., 2001). So far no studies have been conducted using rock glaciers as indicators for the presence of permafrost on the northern side of the Himalaya. Further north, the extremely dry and cold conditions on the Tibetan Plateau have resulted in a variety of permafrost related features for which no occurrences in other mountain ranges are described (Harris et al., 1998).

For remote-sensing-based derivation of glacier outlines over large areas often ASTER and Landsat TM have been used. Data from higher resolution sensors have rarely been applied over larger areas due to costs and availability (e.g., Paul et al., 2013). With ASTER and Landsat TM images at resolution of $15 \mathrm{~m}$ and coarser, automated mapping of rock glaciers proved to be very challenging (Janke, 2001; Brenning, 2009). On a local scale, rock glaciers have been successfully mapped using aerial photography in the Chilean Andes (Brenning, 2005), the Russian Altai mountains (Fukui et al., 2007b), Norway (Lilleøren and Etzelmüller, 2011), and Iceland (Lilleøren et al., 2013). The release of freely available high-resolution satellite images (i.e., Google Earth), which approach the quality of aerial photographs, opened up new possibilities. The images used in Google Earth are SPOT Images or products from DigitalGlobe (e.g., Ikonos, QuickBird), and they are georectified with a DEM based on the Shuttle Radar Topography Mission (SRTM) data, which have a $90 \mathrm{~m}$ resolution in the research area. In mountain regions horizontal inaccuracy for the SRTM DEM can be of the 
same order, as Bolch et al. (2008) reported from the Khumbu region in Nepal.

\section{Methods}

Inferring approximate patterns of permafrost occurrence from rock glacier mapping requires four major steps: (a) identification of rock glaciers and their status (intact vs. relict), (b) mapping of the rock glaciers, (c) regional aggregation to obtain a minimum elevation, and (d) a method to identify the potential candidate area in which rock glaciers can be expected based on topography and other environmental conditions. These four steps are described in the following subchapters.

\subsection{Identification of rock glaciers and their status}

Rock glaciers were visually identified based on their flow patterns and structure. These included transversal flow structures (ridges and furrows), longitudinal flow structures, frontal appearance, and the texture difference of the rock glacier surfaces compared to the surrounding slopes. The most likely origin of the ice was not used as an exclusion criterion, and thus features containing glacier derived ice were also considered as rock glaciers. The state of rock glaciers was estimated based on the visibility of a front with the appearance of fresh material exposed as well as an overall convex and full shape.

These rules were formulated in guidelines containing example images. The mapping was guided by the recording of attributes (Table 1). The recording of these attributes supported a structured evaluation of each landform identified as a rock glacier and provided subjective confidence scores.

\subsection{Mapping of rock glaciers}

The samples to map rock glaciers in Google Earth were created in the free statistical software R (R Core Team, 2014). Each sample consists of one square polygon with a specified latitudinal width $\left(^{\circ}\right)$. The following approximate adjustment for the longitudinal width $\left(^{\circ}\right)$ has been applied, where LAT $\left({ }^{\circ}\right)$ is the latitude for the specific sample.

longitudinal width $=\frac{\text { latitudinal width }}{\cos \left(\frac{\pi \cdot \text { LAT }}{180}\right)}$

To achieve a random distribution, the investigation area was tessellated with potential sample polygons, from which a predefined number of polygons were randomly selected using the $\mathrm{R}$ function sample. Every sample received a unique name consisting of two capital letters and three numbers. With the $\mathrm{R}$ function kmlPolygons from the maptools package (Bivand and Lewin-Koh, 2013) samples were exported into a Keyhole Markup Language (kml) file, which is the main data format supported by Google Earth.
Table 1. Attributes derived during rock glacier mapping. They are recorded in the description field of each rock glacier outline as described in the supplement to this publication.

\begin{tabular}{|c|c|c|}
\hline Attributes & Classification & Code \\
\hline Image date & MMDDYYYY & \\
\hline \multirow{3}{*}{ Upslope boundary } & Glacial & BG \\
\hline & Slope & BS \\
\hline & Unclear & $\mathrm{BU}$ \\
\hline \multirow{3}{*}{ Likelihood active } & Virtually certain & AVC \\
\hline & High & $\mathrm{AH}$ \\
\hline & Medium & $\mathrm{AM}$ \\
\hline \multirow{3}{*}{ Longitudinal flow structure } & Clear & $\mathrm{LC}$ \\
\hline & Vague & LV \\
\hline & None & $\mathrm{LN}$ \\
\hline \multirow{3}{*}{ Transversal flow structure } & Clear & $\mathrm{TC}$ \\
\hline & Vague & TV \\
\hline & None & $\mathrm{TN}$ \\
\hline \multirow{3}{*}{ Front } & Steep & FS \\
\hline & Gentle & FG \\
\hline & Unclear & $\mathrm{FU}$ \\
\hline \multirow{3}{*}{ Outline } & Clear & $\mathrm{OC}$ \\
\hline & Fair & OF \\
\hline & Vague & OV \\
\hline \multirow{3}{*}{ Snow coverage } & Snow & SS \\
\hline & Partial snow & SP \\
\hline & No snow & SN \\
\hline \multirow{3}{*}{ Overall confidence } & Virtually certain & $\mathrm{CVC}$ \\
\hline & High & $\mathrm{CH}$ \\
\hline & Medium & $\mathrm{CM}$ \\
\hline
\end{tabular}

Google Earth is frequently used to display scientific results (e.g., Scambos et al., 2007; Gruber, 2012) but in some cases also as a data source (e.g., Sato and Harp, 2009). Neither spectral nor spatial properties of the displayed satellite images are easily accessible. Thus the accuracy of the used remote sensing images and any created output is hard to quantify. Potere (2008) showed that the horizontal accuracy of 186 points in 46 Asian cities has a mean root mean square error of $44 \mathrm{~m}$ when comparing them to Landsat GeoCover. The accuracy of Google Earth is sufficient for our purposes as the inaccuracy thus arising from horizontal misalignment between imagery and DEM is likely to be smaller than $100 \mathrm{~m}$ vertical.

We mapped 4000 samples within the HKH region. Each sample consists of one square polygon with a latitudinal width of 0.05 decimal degrees equivalent to $5.53 \mathrm{~km}$. Due to the imperfect latitude correction of width, the area per sample varies from $26.1 \mathrm{~km}^{2}$ in the south to $32.2 \mathrm{~km}^{2}$ in the north.

Manually mapped outlines of debris-covered glaciers based on high-resolution images vary significantly, even if 


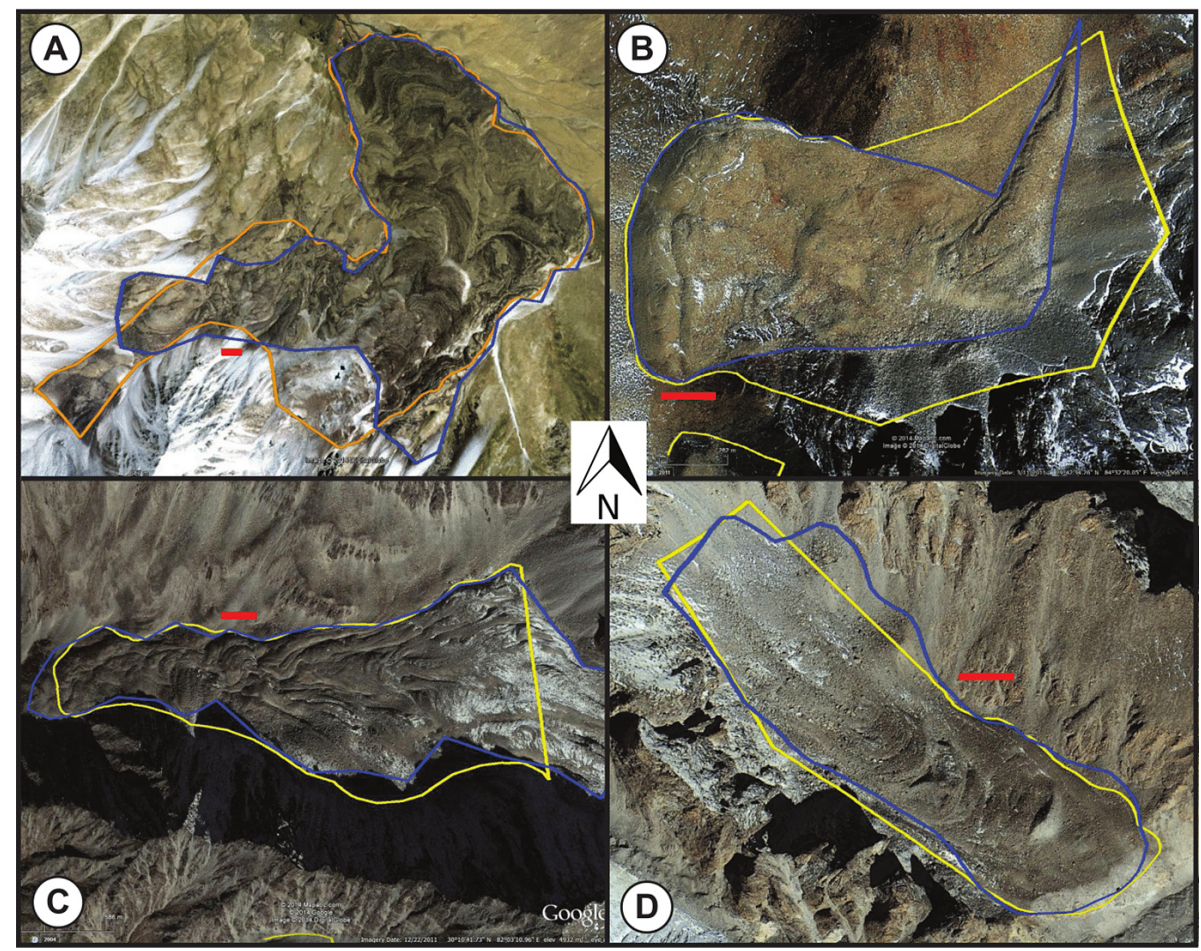

Figure 2. Examples of rock glaciers mapped by two different persons (red line $=100 \mathrm{~m}$ ). Coordinates (lat/long) are for (a) 37.07/72.92; (b) $29.71 / 84.54$; (c) $30.18 / 82.05$; (d) $30.18 / 82.22$. All copyrights Image ${ }^{{ }} 2014$ DigitalGlobe.

mapped by experts (Paul et al., 2013). Due to similar visual properties, the same kind of issues can be expected when mapping rock glaciers. To reduce subjectivity, every sample was mapped by two persons independently. This was done by three people with expertise based on their field of study (two holding a MSc in Glaciology and one holding a MSc in Environmental Science with a focus on periglacial processes) and after 2 months of specific training. Each sample was mapped by two different persons, resulting in two comprehensive mappings (Fig. 2). Mapping guidelines were iteratively updated and improved and the final version of the guidelines was applied consistently to all samples. Regular meetings were held to resolve difficulties in the mapping.

\subsection{Regional aggregation}

The elevation characteristics of the mapped rock glaciers were extracted from SRTM DEM version 4.1 from CGIAR at a spatial resolution of $90 \mathrm{~m}$ (Jarvis et al., 2008) using ArcGIS 10 . For the analysis only the mapped rock glacier area within the sample polygons were taken into account. Afterwards, extreme values (i.e., lowest and highest elevations of rock glacier snouts) were revisited and checked, ensuring plausible results from both mappings. Even though both mappings showed plausible and similar results, for the final analysis we chose to only use areas identified by both persons as rock glaciers. Thus the influence of subjectivity or blunders during the mapping process was further reduced, resulting in a much more conservative and firm data base.

\subsection{The potential candidate area}

For the evaluation of permafrost maps, rock glaciers outside the signatures for permafrost in a map indicate false negatives: the map indicates the likely absence of permafrost, but the existence of permafrost can be inferred based on mapped rock glaciers. A comparison of mapped rock glaciers with predicted permafrost extent, however, is only informative in situations where the formation and observation of rock glaciers can be expected. As part of the analysis we identify the "potential candidate area", i.e., areas, where there is a chance to map rock glaciers. This is important, as the absence of mapped rock glaciers from flat areas, from glaciers, or in areas with insufficient image quality is to be expected. The potential candidate area includes only sample areas, which fulfil all of the following three criteria. (a) Topography: the standard deviation of the SRTM $90 \mathrm{~m}$ DEM within the sample polygon is larger $85 \mathrm{~m}$. This threshold was chosen so as to be smaller than the lowest observed value where rock glaciers were mapped, which is $89.5 \mathrm{~m}$. (b) Image quality: only samples with sufficient image quality are taken into account. (c) Absence of glaciers: glacier-covered areas were excluded based on the glacier inventory published by Bajracharya and Shrestha (2011), which largely covers the $\mathrm{HKH}$ region with the exception of parts of China. 


\section{Results and discussion}

\subsection{Data and data quality}

Of the 4000 samples $3432(86 \%)$ received the same classification by both mapping persons: $70 \%$ did not have any rock glaciers, $12 \%$ had insufficient quality, and $4 \%$ contained rock glaciers (Fig. 3). Those $4 \%$ translate into 155 samples with 702 rock glaciers in total. In $3 \%$ of all samples only one mapping contained rock glaciers but the other did not.

The spatial distribution of classified samples shows that nearly all mapped rock glaciers are located within the Himalayan arc (Fig. 3). Only very few samples on the Tibetan Plateau contained rock glaciers. Also, the samples with insufficient quality of the Google Earth images show distinct patterns, concentrated along the Himalayan arc and eastern part of the Tibetan Plateau. However, as the reasons for insufficient image qualities were not noted down, no exact statements can be made. Impressions from the involved analysts were that in the Himalayan arc this was mainly due to snow cover and on the eastern Tibetan Plateau mainly due to very coarse image resolutions. Clouds were only an issue in a few cases.

The high resolution of Google Earth images and the rigorous exclusion of samples with poor image quality made it possible to discriminate rock glaciers from other (similar) landforms. It was possible to assess visually the steepness or activity of the rock glacier front and the characteristic of transversal and longitudinal flow structures, providing a subjectively acceptable, but here not objectively testable, level of confidence in interpreting landforms as indicators for the presence of permafrost. Vegetation coverage on a rock glacier was only identified in two sample polygons in the whole $\mathrm{HKH}$ region and is either absent in the investigation area or not visible based on the imagery available. In European mountains, vegetation cover has often been taken as an indication of relict rock glaciers (Cannone and Gerdol, 2003) but this concept is difficult to generalize to other mountain ranges. The two cases mapped here have been disregarded for further analysis.

On the scale of one sample polygon, the mapped outlines of rock glaciers varied considerably between the two mappings by the analysts. Major differences occurred especially in the somewhat arbitrary delineation of the upper boundary of rock glaciers and the separation between individual objects, whereas a higher congruence existed for the termini of mapped rock glaciers (Fig. 4). This resulted in relatively small differences when comparing the mean minimum elevation of all mapped rock glaciers per sample from the two mappings. The mean difference between the two mappings is $46 \mathrm{~m}$ (Fig. 4). Samples with high differences were mostly a result of a different number of mapped rock glaciers.

The differences in sample size with changing latitude are not expected to influence the results for the minimum elevation of rock glaciers per sample. A slight error biased to-

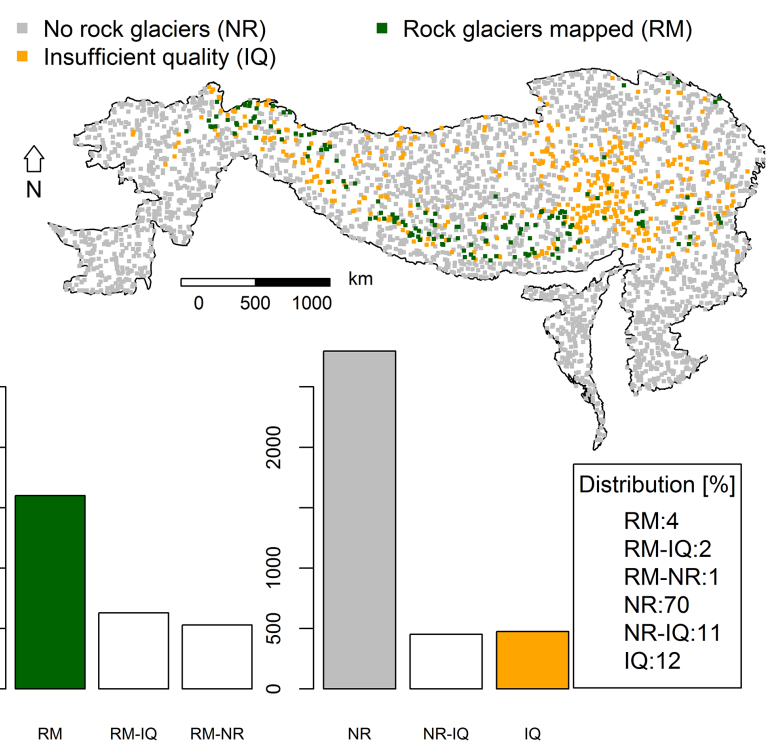

Figure 3. Overview of mapping results. All 3432 samples with the same classification from both mappings are shown. In the bar plots, identically classified samples are shown with filled bars and samples, which were classified differently in white. Bars with only one abbreviation (e.g., RM) mean that both mapping persons had the same classification of the sample (e.g., rock glacier mapped), whereas two abbreviations (e.g., RM-IQ) mean that the mappings resulted not in the same classification (once rock glacier mapped, once insufficient quality). Note that the difference in scale between the samples containing rock glaciers on the left and all others samples on the right is 1 order of magnitude.

wards a higher minimum elevation for rock glaciers can be expected due to rock glaciers which are only partially within the mapped sample. In those cases their lowest point has been taken at the sample boarder and not at the rock glacier snout. With respect to the comparably large data base, inaccuracies originating from neither Google Earth nor the SRTM DEM should distort the further products.

This estimation of data quality can be put into perspective by comparing with findings from other mountain ranges and by comparing with expected maximum uncertainty in the permafrost maps to be evaluated. In the European Alps, a difference of about $2{ }^{\circ} \mathrm{C}$ (Table 2 of Boeckli et al., 2012) in mean annual air temperature has been found between intact and relict rock glaciers, providing an order of magnitude for possible errors induced by misinterpretation of rock glacier status. Gruber (2012) uses well-established approximations of permafrost occurrence based on mean annual air temperature to estimate permafrost occurrence. At the same time, that publication shows differences of more than $4{ }^{\circ} \mathrm{C}$ in longterm mean annual air temperature between differing gridded data products. Given that this is likely a conservative estimate of the true error in these data products and considering the spatially diverse lapse rates (e.g., Kattel et al., 2013), our uncertainty in pinpointing zones with permafrost in the moun- 

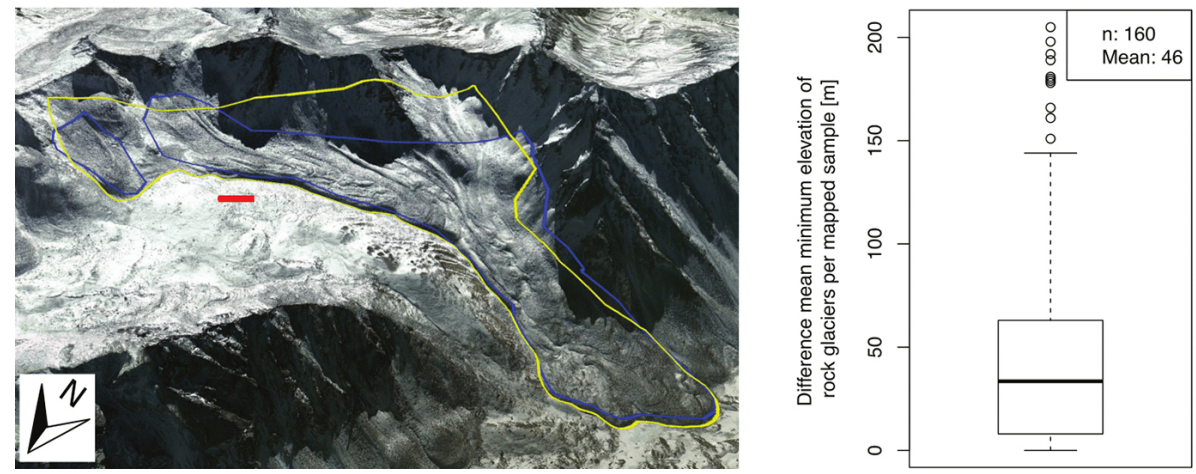

Figure 4. Example of differences between two mappings on the left (red line $=100 \mathrm{~m}$ ). Image ${ }^{{ }} 2014$ DigitalGlobe. For the box plot on the right only samples where both analysts have mapped rock glaciers were taken into account. The samples with big differences typically have only few rock glaciers; therefore if one object got mapped by only one analyst the mean minimum elevation could change significantly.

tainous $\mathrm{HKH}$ is likely to be much larger than $6^{\circ} \mathrm{C}$, or about $600-1000 \mathrm{~m}$ in elevation. Even with the uncertainty due to imperfect identification of rock glaciers and their activity status, systematic mapping of rock glaciers can reduce this uncertainty - or point to differences between the mapping and simulations based on air temperature fields where additional research is needed. Furthermore, the documentation of visible signs of permafrost throughout the region is important in supporting the growing realization that permafrost really does occur in these mountains.

\subsection{Regional rock glacier distribution}

Minimum elevations reached by rock glaciers are expressed as a mean on the sample scale $\left(\sim 30 \mathrm{~km}^{2}\right)$, taking into account the lowermost points of all mapped rock glaciers and thus resulting in a mean minimum elevation per sample. This provides a more robust and conservative measure than a minimum value but also implies that some rock glaciers do reach lower elevations than indicated by the sample mean value. Mean minimum elevations reached by rock glaciers per sample vary significantly in the HKH region (Fig. 5). They are a few hundred meters lower than what previous, more local, studies have reported for Nepal (Jakob, 1992; Ishikawa et al., 2001) and match well with previous reports from Pakistan (Owen and England, 1998). The lowest elevation was recorded in northern Afghanistan at $3554 \mathrm{~m}$ a.s.l. and the highest elevation at $5735 \mathrm{~m}$ a.s.l. on the Tibetan Plateau. If variations within close proximity occur, they follow regional patterns. The most pronounced shift of the mean minimum elevation reached by rock glaciers occurs between the southern and the northern side of the Himalaya, where the mean minimum elevation rises several hundred meters within a short distance.

\subsection{Assessment of permafrost distribution maps}

Figures 6 and 7 show how the termini of the mapped rock glaciers relate to the signatures of the maps evaluated. The

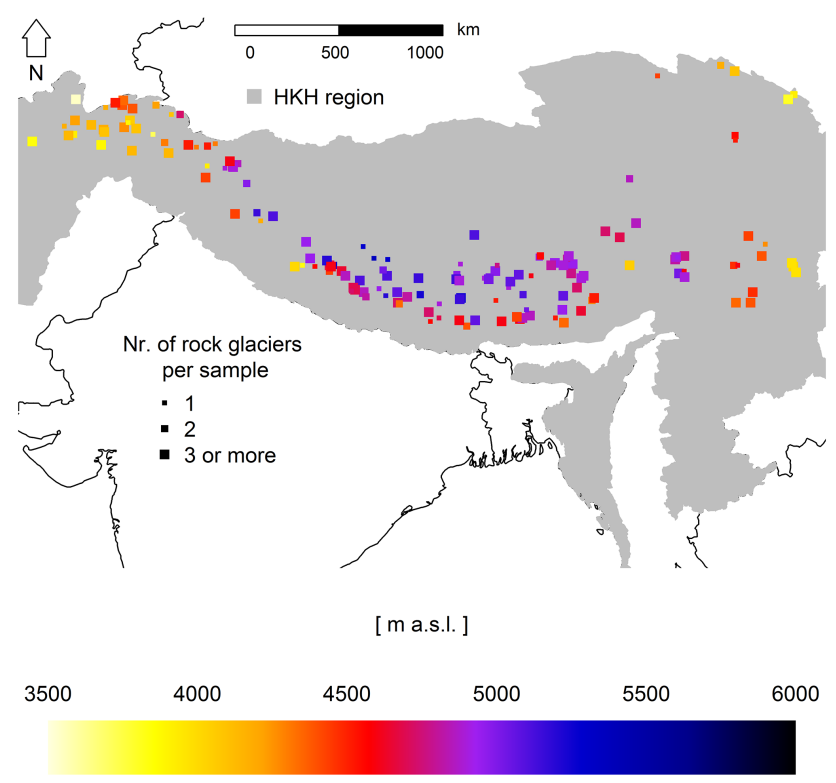

Figure 5. Mean minimum elevation of rock glaciers per sample. The size of the square indicates how many rock glaciers this value is based on. This is for $24 \%$ one rock glacier, for $18 \%$ two rock glaciers, and for $58 \%$ between 3 and 21 rock glaciers.

mapped rock glaciers are distributed evenly over all classes of the PZI (Fig. 6). Rock glacier density per class peaks for the medium PZI values and decreases towards both ends of the spectrum. The decrease is more pronounced towards lower PZI values (lower possibility of permafrost). Only 5 out of more than 700 mapped rock glaciers are reaching areas outside the PZI. Thus the PZI is in good agreement with our study, based on this summary evaluation.

When comparing the mapped rock glaciers with the IPA map (Fig. 7) the investigation area and the mapped rock glaciers are predominantly in the two classes "discontinuous permafrost" and "sporadic permafrost". A small part of the investigation area and a few mapped rock glaciers are in 


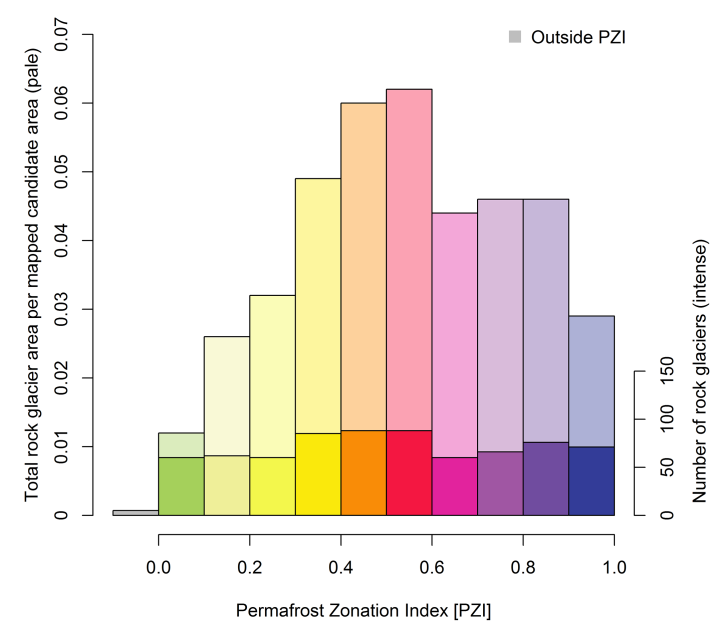

Figure 6. Mapped rock glaciers in relation to the Permafrost Zonation Index summarized over the mapped HKH region. Mapped candidate area refers to areas in which rock glaciers can be expected to occur and to be observed; for each pixel, this is determined based on (a) topography (standard deviation of SRTM90 $>85 \mathrm{~m}$ in each sample), (b) sufficient image quality in Google Earth, and (c) the absence of glacier cover. The same colors as for the PZI map have been used where dark blue indicates permafrost in nearly all conditions and bright yellow indicates permafrost only in very favorable conditions. Green indicates the fringe of uncertainty. Intensive colors indicate the number of rock glaciers and pale colors represent the density of rock glaciers within a certain class. For more information on the PZI see Gruber (2012).

the class "isolated permafrost". The class "continuous permafrost" does not exist in the HKH region. More than 250 of the mapped rock glaciers are outside the IPA map permafrost signature. Thus the IPA map does not coincide well with the findings from our study. This is likely due to simplification and subjectivity in the applied manual mapping, but in part may stem from inaccuracies in the digitization and coordinate transformation of the map into the digital product available from NSIDC.

\subsection{Regional comparison with the Permafrost Zonation Index}

Spatial patterns of the agreement between the PZI and the mapped rock glaciers are shown in Fig. 8 aggregated to $1^{\circ} \times 1^{\circ}$ resolution. Mapped rock glaciers are reaching low PZI values in most parts of the investigation area and thus indicate a good agreement. The lowest elevation of mapped rock glacier remains in high PZI values, despite the presence of low PZI values only for the northern side of the central part of the Himalayan arc, thus showing that the minimum elevation reached by rock glaciers and the predicted lowermost occurrence of permafrost are not in agreement. Therefore, either the PZI (due to its method or its driving data) fails to reproduce the local permafrost conditions or the conditions for

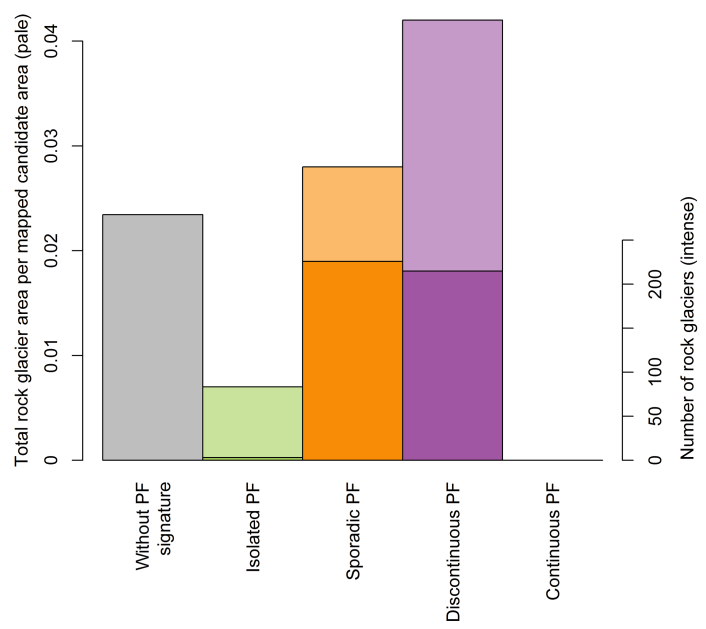

Figure 7. Comparison of all mapped rock glaciers with the CircumArctic Map of Permafrost (IPA map). Note that the category "continuous permafrost" does not occur in the investigation area. "Mapped candidate area" refers to areas in which rock glaciers can be expected to occur and to be observed; for each pixel, this is determined based on (a) topography (standard deviation of SRTM90 $>85 \mathrm{~m}$ in each sample), (b) sufficient image quality in Google Earth, and (c) the absence of glacier cover. Intensive colors indicate the number of rock glaciers and pale colors represent the density of rock glaciers within a certain class.

rock glacier development in the particular area are different from other areas of the region. This may partially be caused by the topography of the Tibetan Plateau, where the lower elevations, and thus lower PZI values, correspond to a flatter topography. Further, there are very distinctive climatic conditions in this region, with a strong south-north precipitation gradient due to the Himalaya blocking the summer monsoon on the southern slopes, resulting in extremely dry and continental conditions on the Tibetan Plateau. Consequently, we assume that rock glaciers may not reach the predicted lowermost occurrence of permafrost as they may not form because of sparse supply of snow to be incorporated in aggrading debris. But to test this hypothesis further, more detailed investigations are needed.

\section{Conclusions}

Comparison of the two rock glacier mappings showed relatively small differences, as described in Sect. 4.1, indicating that the proposed mapping procedure works consistently. By using only the intersected area from two independent mappings, subjectivity as described for the manual delineation of debris-covered glaciers by Paul et al. (2013) could further be reduced. Thus the use of Google Earth as a data source to map rock glaciers in a data sparse region is shown to be feasible. 


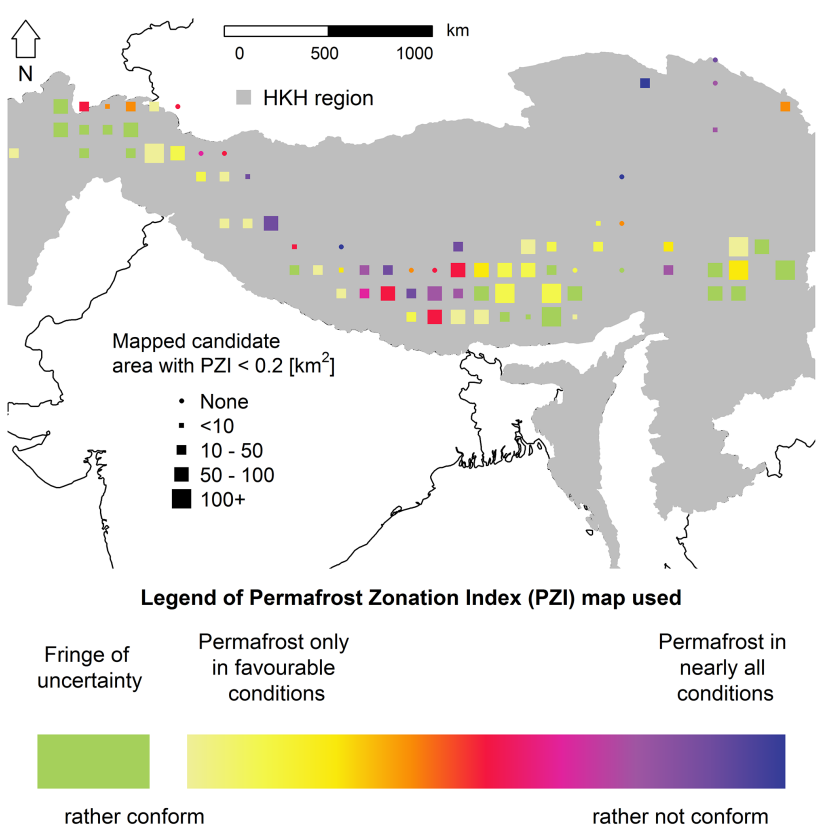

Figure 8. Spatial patterns of agreement between mapped rock glaciers and PZI. Color indicates the lowest PZI value in the mapped rock glaciers within each $1^{\circ} \times 1^{\circ}$ square. Green and yellow are signalling an apparent good agreement between lowest elevations reached by rock glaciers and predicted lowest possible elevations for permafrost by the PZI. The size of square symbols indicates the size of the mapped candidate area with PZI $<0.2$. This is a proxy for whether or not rock glaciers with low PZI values can be expected in this area.

The diversity of the climate in the investigation area leads to a wide morphological range of rock glaciers, or features of apparently moving debris, exceeding what is commonly observed in Europe and North America. Over the whole investigation area, the minimum elevation of rock glaciers varies from $3500 \mathrm{~m}$ a.s.1. in northern Afghanistan to more than $5500 \mathrm{~m}$ a.s.l. on the Tibetan Plateau. A clear increase in the minimum elevation reached by rock glaciers can be observed towards the Tibetan Plateau.

There are two permafrost distribution maps available for the HKH region: the IPA map with manually delineated permafrost classes (Brown et al., 1998) and the PZI which is based on a simple computer model (Gruber, 2012). Comparing these two maps with the mapped rock glaciers from our study is a first step in assessing their quality for the remote and data-sparse mountainous parts of the HKH region. The IPA map falls short in adequately representing local permafrost conditions with more than 250 of the mapped rock glaciers falling outside its permafrost signature. The PZI map and the rock glacier mapping on the other hand are in good agreement, with only five mapped rock glaciers being outside the PZI. Based on the information available, PZI does indicate areas where no permafrost can be expected rather well and is currently the best prediction of the permafrost distribution in the HKH region.

In most areas, the lowermost mapped rock glaciers coincide with low PZI values. There is, however, a disagreement in the central part of the region, where rock glaciers do not reach down to elevations with low PZI values. This disagreement can inform further research and it underscores the importance of using the presence of rock glaciers as an indicator of permafrost but to not use their absence as an indicator of permafrost free conditions. The comparison with the rock glacier mapping is a first step towards more thorough testing of the PZI and other models and map products for this remote and data-sparse region.

\section{Data availability}

The rock glacier mapping, the source code to create the random samples, the outline of the HKH region, and a manual for the mapping of rock glaciers in Google Earth are published as a Supplement. Both mappings include all 4000 samples and all mapped rock glaciers. Different colors indicate the different persons involved in the mapping. Those files come in KML (Keyhole Markup Language) and can be opened with Google Earth and most GIS software. The file f.RandomPolygon.r contains the $\mathrm{R}$ function to create the samples.

\section{The Supplement related to this article is available online at doi:10.5194/tc-9-2089-2015-supplement.}

Author contributions. M.-O. Schmid developed the method, conducted the analysis, and prepared the manuscript. S. Gruber conceived the study and supervised the development of the method and the analysis and contributed significantly to the writing. P. Baral, S. Shahi, and T. Shrestha did the mapping and provided general support. D. Stumm and P. Wester contributed to conceiving the study, secured funding, provided overall supervision, and contributed to the writing.

Acknowledgements. This study was supported by ICIMOD through core funding by the Department for International Development (DFID) of the UK and by the governments of Afghanistan, Australia, Austria, Bangladesh, Bhutan, China, India, Myanmar, Nepal, Norway, Pakistan, and Switzerland. The views and interpretations in this publication are those of the authors. They are not necessarily attributable to ICIMOD and do not imply the expression of any opinion by ICIMOD concerning the legal status of any country, territory, city, or area of its authority, the delimitation of its frontiers or boundaries, or the endorsement of any product.

Edited by: T. Zhang 


\section{References}

Bajracharya, S. and Shrestha, B.: The status of glaciers in the Hindu Kush-Himalayan region, ICIMOD, Kathmandu, 2011.

Bivand, R. and Lewin-Koh, N.: maptools: Tools for reading and handling spatial objects, available at: http://cran.r-project.org/ package $=$ maptools, last access: 21 October 2013.

Boeckli, L., Brenning, A., Gruber, S., and Noetzli, J.: A statistical approach to modelling permafrost distribution in the European Alps or similar mountain ranges, The Cryosphere, 6, 125-140, doi:10.5194/tc-6-125-2012, 2012.

Bolch, T., Buchroithner, M., Pieczonka, T., and Kunert, A.: Planimetric and volumetric glacier changes in the Khumbu Himal, Nepal, since 1962 using Corona, Landsat TM and ASTER data, J. Glaciol., 54, 592-600, doi:10.3189/002214308786570782, 2008.

Bolch, T., Kulkarni, A., Kääb, A., Huggel, C., Paul, F., Cogley, J. G., Frey, H., Kargel, J. S., Fujita, K., Scheel, M., Bajracharya, S., and Stoffel, M.: The state and fate of Himalayan glaciers., Science, 336, 310-331, doi:10.1126/science.1215828, 2012.

Brenning, A.: Geomorphological, hydrological and climatic significance of rock glaciers in the Andes of Central Chile $\left(33-35^{\circ} \mathrm{S}\right)$, Permafrost Periglac. Process., 16, 231-240, doi:10.1002/ppp.528, 2005.

Brenning, A.: Benchmarking classifiers to optimally integrate terrain analysis and multispectral remote sensing in automatic rock glacier detection, Remote Sens. Environ., 113, 239-247, doi:10.1016/j.rse.2008.09.005, 2009.

Brown, J., Ferrians, O., Heginbottom, J. A., and Melnikov, E.: Circum-Arctic Map of Permafrost and Ground-Ice Conditions, USA Natl. Snow Ice Data Center, Boulder, Colorado, 1998.

Cannone, N. and Gerdol, R.: Vegetation as an Ecological Indicator of Surface Instability in Rock Glaciers, Arct. Antarct. Alp. Res., 35, 384-390, doi:10.1657/15230430(2003)035[0384:VAAEIO]2.0.CO;2, 2003.

Capps, S. R.: Rock Glaciers in Alaska, J. Geol., 18, 359-375, 1910.

Cheng, G. and Wu, T.: Responses of permafrost to climate change and their environmental significance, Qinghai-Tibet Plateau, J. Geophys. Res., 112, F02S03, doi:10.1029/2006JF000631, 2007.

Fukui, K., Fujii, Y., Ageta, Y., and Asahi, K.: Changes in the lower limit of mountain permafrost between 1973 and 2004 in the Khumbu Himal, the Nepal Himalayas, Global Planet. Change, 55, 251-256, doi:10.1016/j.gloplacha.2006.06.002, 2007a.

Fukui, K., Fujii, Y., Mikhailov, N., Ostanin, O., and Iwahana, G.: The lower limit of mountain permafrost in the Russian Altai Mountains, Permafrost Periglac. Process., 18, 129-136, doi:10.1002/ppp.585, 2007b.

Gruber, S.: Derivation and analysis of a high-resolution estimate of global permafrost zonation, The Cryosphere, 6, 221-233, doi:10.5194/tc-6-221-2012, 2012.

Haeberli, W.: Creep of mountain permafrost: internal structure and flow of alpine rock glaciers, Mitteilungen der Versuchsanstalt fur Wasserbau, Hydrol. und Glaziologie an der ETH Zurich, Zurich, 5-142, 1985.

Haeberli, W., Hallet, B., Arenson, L., Elconin, R., Humlum, O., and Ka, A.: Permafrost Creep and Rock Glacier Dynamics, Permafrost Periglac. Process., 17, 189-214, doi:10.1002/ppp.561, 2006.

Harris, S. A., Zhijiu, C., and Guodong, C.: Origin of a bouldery diamicton, Kunlun Pass, Qinghai-Xizang Plateau, Peo- ple's Republic of China: gelifluction deposit or rock glacier?, Earth Surf. Proc. Land., 23, 943-952, doi:10.1002/(SICI)10969837(199810)23:10<943::AID-ESP913>3.0.CO;2-7, 1998.

Heginbottom, J. A.: Permafrost mapping: a review, Prog. Phys. Geogr., 26, 623-642, doi:10.1191/0309133302pp355ra, 2002.

Heginbottom, J. A., Brown, J., Melnikov, E. S., and O.J. Ferrians, J.: Circum-arctic map of permafrost and ground ice conditions, Proc. Sixth Int. Conf. Permafrost, 5-9 July 1993, Beijing, China, 255-260, 1993.

Hewitt, K.: Glaciers of the Karakoram Himalaya, Springer Netherlands, Dordrecht, 2014.

IPCC: Summary for Policymakers, in: Climate Change 2014: Impacts, Adaptation, and Vulnerability, Part A: Global and Sectoral Aspects, Contribution of Working Group II to the Fifth Assessment Report of the Intergovernmental Panel on Climate Change, edited by: Field, C. B., Barros, V. R., Dokken, D. J., Mach, K. J., Mastrandrea, M. D., Bilir, T. E., Chatterjee, M., Ebi, K. L., Estrada, Y. O., Genova, R. C., Girma, B., Kissel, E. S., Levy, A. N., MacCracken, S., Mastrandrea, P. R., and White, L. L., Cambridge University Press, Cambridge, UK and New York, NY, USA, 1-32, 2014.

Ishikawa, M., Watanabe, T., and Nakamura, N.: Genetic differences of rock glaciers and the discontinuous mountain permafrost zone in Kanchanjunga Himal, Eastern Nepal, Permafrost Periglac. Process., 12, 243-253, doi:10.1002/ppp.394, 2001.

Jakob, M.: Active rock glaciers and the lower limit of discontinuous alpine permafrost, Khumbu Himalaya, Nepal, Permafrost Periglac. Process., 3, 253-256, 1992.

Janke, J. R.: Rock Glacier Mapping: A Method Utilizing Enhanced TM Data and GIS Modeling Techniques, Geocarto Int., 16, 5-15, doi:10.1080/10106040108542199, 2001.

Jarvis, A., Reuter, H. I., Nelson, A., and Guevara, E.: Hole-filled SRTM for the globe Version 4, available at: http://srtm.csi.cgiar. org (last access: 21 October 2013), 2008.

Kattel, D. B., Yao, T., Yang, K., Tian, L., Yang, G., and Joswiak, D.: Temperature lapse rate in complex mountain terrain on the southern slope of central Himalayas, Theor. Appl. Climatol., 113, 671-682, doi:10.1007/s00704-012-0816-6, 2013.

Lilleøren, K. S. and Etzelmüller, B.: A regional inventory of rock glaciers and ice-cored moraines in norway, Geogr. Ann. A, 93, 175-191, doi:10.1111/j.1468-0459.2011.00430.x, 2011.

Lilleøren, K. S., Etzelmüller, B., Gärtner-Roer, I., Kääb, A., Westermann, S., and Guðmundsson, Á.: The Distribution, Thermal Characteristics and Dynamics of Permafrost in Tröllaskagi, Northern Iceland, as Inferred from the Distribution of Rock Glaciers and Ice-Cored Moraines, Permafrost Periglac. Process., 24, 322-335, doi:10.1002/ppp.1792, 2013.

Owen, L. A. and England, J.: Observations on rock glaciers in the Himalayas and Karakoram Mountains of northern Pakistan and India, Geomorphology, 26, 199-213, doi:10.1016/S0169555X(98)00059-2, 1998.

Paul, F., Barrand, N. E., Baumann, S., Berthier, E., Bolch, T., Casey, K., Frey, H., Joshi, S. P., Konovalov, V., Bris, R. Le, Mölg, N., Nosenko, G., Nuth, C., Pope, A., Racoviteanu, A., Rastner, P., Raup, B., Scharrer, K., Steffen, S., and Winsvold, S.: On the accuracy of glacier outlines derived from remote-sensing data, Ann. Glaciol., 54, 171-182, doi:10.3189/2013AoG63A296, 2013. 
Potere, D.: Horizontal Positional Accuracy of Google Earth's High-Resolution Imagery Archive, Sensors, 8, 7973-7981, doi:10.3390/s8127973, 2008.

Ran, Y., Li, X., Cheng, G., Zhang, T., Wu, Q., Jin, H., and Jin, R.: Distribution of Permafrost in China: An Overview of Existing Permafrost Maps, Permafrost Periglac. Process., 23, 322-333, doi:10.1002/ppp.1756, 2012.

R Core Team: R: A Language and Environment for Statistical Computing, available at: http://www.r-project.org/, last access: 15 June 2014.

Regmi, D.: Rock Glacier distribution and the lower limit of discontinuous mountain permafrost in the Nepal Himalaya, Proc. Ninth Int. Conf. Permafr. (NICOP), 29 June-3 July 2008, Fairbanks, Alaska, 1475-1480, 2008.

Sato, H. P. and Harp, E. L.: Interpretation of earthquake-induced landslides triggered by the 12 May 2008, M.9 Wenchuan earthquake in the Beichuan area, Sichuan Province, China using satellite imagery and Google Earth, Landslides, 6, 153-159, doi:10.1007/s10346-009-0147-6, 2009.
Scambos, T., Haran, T., Fahnestock, M. A., Painter, T. H., and Bohlander, J.: MODIS-based Mosaic of Antarctica (MOA) data sets: Continent-wide surface morphology and snow grain size, Remote Sens. Environ., 111, 242-257, doi:10.1016/j.rse.2006.12.020, 2007.

Shroder, J. F., Bishop, M. P., Copland, L., and Sloan, V. F.: Debriscovered Glaciers and Rock Glaciers in the Nanga Parbat Himalaya, Pakistan, Geogr. Ann. A, 82, 17-31, doi:10.1111/j.04353676.2000.00108.x, 2000.

Yang, M., Nelson, F. E., Shiklomanov, N. I., Guo, D., and Wan, G.: Permafrost degradation and its environmental effects on the Tibetan Plateau: A review of recent research, Earth-Sci. Rev., 103, 31-44, doi:10.1016/j.earscirev.2010.07.002, 2010.

Zhang, T.: Historical Overview of Permafrost Studies in China, Phys. Geogr., 26, 279-298, doi:10.2747/0272-3646.26.4.279, 2005. 